\title{
Effect of Different Anabaena variabilis (Kütz) Treatments on Some Growth Parameters and Physiological Aspects of Hordeum vulgare L. and Trigonella foenum-graecum $\mathrm{L}$.
}

\author{
Gehan A. Ismail ${ }^{\#}$ and Shaimaa A. Abo-Hamad \\ Botany Department, Faculty of Science, Tanta University, Tanta, Egypt.
}

\begin{abstract}
CYANOBACTERIA are a diverse group of prokaryotes which occupies many environments. In terrestrial habitats, they were famed to benefit both soil and plants through releasing bioactive substances of various biological functions. In the present study four treatments of Anabaena variabilis (seeds primed in 1\% fresh cyanobacterial extract, seeds sown in soils inoculated with $3 \mathrm{~g}$ fresh or dry cyanobacterial cells per $1 \mathrm{~kg}$ soil and wet seeds primed with $3 \mathrm{~g}$ dry cyanobacterial powder per $1 \mathrm{~kg}$ seeds) were examined for their effect on Hordeum vulgare and Trigonella foenum-graecum L. plants. All treatments increased the germination percentage, shoot length, fresh and dry weights. The photosynthetic pigments, proteins, glutamic-oxaloacetic and glutamic-pyruvic transaminases (GOT and GPT) activities were also markedly increased specially in seeds primed with cyanobacterium dried cells. The protein profile of Hordeum vulgare seedlings revealed the appearance of newly formed protein band with molecular weight of $220 \mathrm{KDa}$ in response to soaking the seeds in fresh cells extract. On the other hand, the protein profile of Trigonella foenum-graecum L. shows the induction of low molecular weight protein bands 10-14 KDa with all treatments. The plant growth promotive effect was attributed to the bioactive materials like phytohormones, exopolysaccharides, nitrogen, phosphorus and potassium estimated in the cyanobacterial biomass. The results recommended bio-priming the seeds of the two examined plants in dried cyanobacterial biomass as an economical and safe route fertilizer.
\end{abstract}

Keywords: Cyanobacteria, Transaminase enzymes, Gel electrophoreses, Biofertilizers.

\section{Introduction}

The overuse of synthetic chemicals in agriculture has resulted in great ecological degradation throughout the world, leading to soil infertility, ocean dead zones, and biodiversity loss (Chagnon et al., 2015). Biofertilizers are environmentally friendly, coast effective, alternative to synthetic fertilizers, for they not only enhance agricultural production but also diminish environmental pollution. The use of microalgae and cyanobacteria as biofertilizers has been experienced as possible solution for the defects resulted from the extensive use of chemicals in agriculture (Kawalekar, 2013).

Many researches recommended cyanobacteria as a biofertilizer for many vegetable crops e.g. sorghum, maize, lentil, chickpea, barley, sugar beet, and bean (Adam, 1999; Hegazi et al., 2010 and El-Naggar et al., 2014) . Cyanobacteria can enrich the soil with micro and macronutrients, plant growth regulators and different bioactive secondary metabolite compounds that inhibit the growth of soil pathogenic bacteria and fungi
(Karthikeyan et al., 2007). In addition they secrete mucilage and polysaccharide materials that improve soil structure, porosity, aggregation stability and fertility, thus enabling recovery of poor soils and increase plant growth (Osman et al., 2005 and Maqubela et al., 2008) .

Seed treatment is a technique in which several organic, inorganic and biotic materials are added to seed by adhesive agents. This can be performed in two major ways: seed hydration (soaking or priming) treatment and coating seed treatment (Taylor et al., 1998). Seed soaking or priming has been defined as "a process by which seeds can be led to absorb nutrients, protectants, growth regulators, etc. by immersing them in appropriate solutions for extended periods" (Scott, 1998). Seed coating is a general term for the application of finely ground soils or liquids containing dissolved or suspended solids to form a more or less continuous layer covering the natural seed coat and includes pelleting and many other seed treatments. By priming, seeds are soaked in

"Corresponding author email: gehan.ismail@science.tanta.edu.eg 
different low molecular weight osmoprotectants solutions to activate germination related metabolic processes. This inhibits seeds from imbibing sufficient water for radical projection, thus seeds remain hanging longer time in the lag stage of hydration. Additionally, it is a simple, inexpensive, easily trained treatment that increases germination, harmonize and reduces seedling emergence time, and increases stand formation (Taylor et al., 1998). The present-day management policy for agriculture depends on the keen exploration for new- natural biological means capable of protection against pathogens and stimulate vigorous growth in the same time. In this direction, cyanobacterial species were well-known as natural biofertilizers for many crops especially for rice and wheat cultivations, yet scanty studies reported using cyanobacteria as a biopriming agents (Haroun \& Hussein, 2003; Hegazi et al., 2010 and Osman et al., 2016). The cellular extracts and growth medium of several microalgae species have been found to contain phytohormones like gibberellins and cytokinin which are known to play an important roles in plant growth and development. Several studies have found a relation between better nutrient uptake, higher biomass accumulation, and greater crop yields to the use of microalgae biofertilizers (Selvakumar et al., 2012; El-Naggar et al., 2014 and Mohan et al., 2015). Barley is an annual grass. The juice of barley grass contains beta carotene, vitamins B1, B2, B6, B12, pantothenic acid, and folic acid. Minerals present include potassium, calcium, iron, phosphorus, and magnesium. Barley leaf extract has the ability to scavenge free radicals. Trigonella is a winter plant, it is an important medicinal plant and has a great therapeutic effect; it is natural antioxidant source acts as anticancer, decreases serum total lipids and serum cholesterol, enhances insulin sensitivity, and has antidiabetic effect (Prabhu \& Krishnamoorthy, 2010).

The aim of this work was to study the effect of different fresh and dry Anabaena variabilis (Kutz) treatments as biofertilizer on the growth and some physiological aspects of Hordeum vulgare and Trigonella foenum-graecum L. plants.

\section{Materials and Methods}

Growth conditions of cyanobacterium culture and biochemical characterizations

Cyanobacterial strain, A. variabilis (Kutz), was obtained from Phycology Lab., Botany Department, Faculty of Science,TantaUniversity, Egypt. The cyanobacterium was grown on nitratefree $\mathrm{BG}_{11}$ medium (Rippka et al., 1979) for 15 days in $1 \mathrm{~L}$ Erlenmeyer flasks. The culture was incubated under continuous illumination (2500 lux) and temperature of $25^{\circ} \mathrm{C} \pm 2{ }^{\circ} \mathrm{C}$ with constant stirring and aeration.

Culture parameters as $\mathrm{pH}$ value, optical density (OD) and dry weight (DW) were estimated according to (Vonshak, 1986). Chlorophyll pigments were extracted in $90 \%$ acetone and measured spectrophotometrically at 663 and 645nm (Metzner et al., 1965); while carotenes were determined at $480 \mathrm{~nm}$ according to Kirk \& Allen (1965). For phycobiliproteins estimation; the harvested cells were grinded in pestle and mortar in the presence of acetic acid- sodium acetate buffer $(1 \mathrm{M})$ for rupturing cells. After repeated freezing and thawing, the cells were centrifuged and absorbance was read at 498.5, 614 and $651 \mathrm{~nm}$ for phycoerythrin, allophycocyanin and c-phycocyanin, respectively (Kursar et al., 1983). Protein and carbohydrates were estimated using Lowry et al. (1951) and Dubios et al. (1956) methods, respectively. To explore the influence of cyanobacterial treatments on seed germination and seedling development of the tested plants, nitrogenase activity and growth hormones of $A$. variabilis cultures were evaluated. Nitrogenase activity was measured as described by Hardy et al. (1973) while growth hormones (Indole acetic acid (IAA), cytokinins and gibberellins) were determined according to Ünyayar et al. (1996). The exopolysaccharides content of the cyanobacterium cultures was estimated according Sudo et al. (1995) and the fertilizer nutrient value as (N, P and $\mathrm{K}$ ) of the biomass was analyzed according to Allen et al. (1989).

\section{Preparation of cyanobacteria extract and seed treatments}

A. variabilis biomass was harvested by centrifugation after growing for 15 days (beginning of stationary phase) and the cells were washed with distilled water. Cell extracts were made by grinding the biomass with a pestle and blender. $1 \%$ cells extract was prepared by suspending $5 \mathrm{~g}$ grinded fresh cyanobacterial cells in $500 \mathrm{ml}$ distilled water (Shariatmadari et al., 2011).

\section{Plant materials and seed treatments}

Seeds of Hordium vulgare and Trigonella foenum-graecum L. were obtained from the Egyptian Ministry of Agriculture, Giza, Egypt. The seeds were surface sterilized with $0.01 \% \mathrm{HgCl}_{2}$ for $1 \mathrm{~min}$ and then washed several times with distilled water. To evaluate the effect of different application methods of $A$. variabilis on the performance of the 
tested seedlings, four seed treatments were made:

Treatment 1: Seeds primed in water for $12 \mathrm{~h}$ (control).

Treatment 2: Seeds primed in (1\%) fresh cyanobacterial extract for $12 \mathrm{~h}$.

Treatment 3: $\quad$ Seeds directly sown in soils preinoculated with fresh cyanobacterial cells ( $3 \mathrm{~g}$ fresh cells per $1 \mathrm{~kg}$ soil).

Treatment 4: Seeds treated according to the biopriming technique (Reddy, 2013). Seeds were soaked in water for $12 \mathrm{~h}$, after water discharged,seeds were mixed with dry cyanobacterial powder (3 gm dry powder per $1 \mathrm{~kg}$ seeds), arranged as a heap, raped in a jute cloth and kept under this high relative humidity conditions and a temperature of $25-30^{\circ} \mathrm{C}$ for another $12 \mathrm{~h}$.

Treatment 5: Seeds directly sown in soils preinoculated with dry cyanobacterial cells ( $3 \mathrm{~g}$ dry cells per $1 \mathrm{~kg}$ soil).

After each treatment, the seeds were left to grow in plastic pots (10 seeds / pot) $16 \mathrm{~cm}$ height and $13 \mathrm{~cm}$ diameter containing 600 gram soil which composed of clay and sand (2:1). Each treatment was replicated 5 times and completely random design was used.Upon germination, the number of germinated seeds was determined and the germination percentage was calculated. After 21 days plants in the vegetative stage were harvested for each treatment. Fresh plants were used for protein gel electrophoresis and fresh leaves were used for assaying of pigments, GOT and GPT enzymes. Shoot length and fresh weight were determined and then dried in an oven at $60^{\circ} \mathrm{C}$ to a constant weight. Dry samples were used for the determination of soluble proteins.

\section{Estimation of photosynthetic pigments}

The pigments in a known weight of fresh leaves were extracted with $85 \%$ cold acetone. The absorbance of the acetone extracts was measured at 663,644 and $452.5 \mathrm{~nm}$ by using a spectrophotometer for the determination of chlorophyll a, chlorophyll $b$ and carotenoids contents according to the method of (Metzner et al., 1965).

\section{Estimation of total soluble proteins}

The total soluble proteins content was measured quantitatively in the borate buffer extract by using the method of Bradford (1976). The protein content was calculated as $\mathrm{mg} / \mathrm{g}$ dry weight using a calibration curve of Bovine Serum Albumin protein.

\section{Estimation of transaminases activity}

Glutamic-oxaloacetic and glutamic-pyruvic transaminases (GOT and GPT) activities were measured in the cell-free extracts using the method described by Bergmeyer (1974). The number of units ( $\mu \mathrm{M}$ keto acid / $\mathrm{ml}$ sample) was calculated using the standard curve of pyruvate.

Qualitative characterization of protein using SDSPAGE

A fresh plant sample was homogenized with $1 \mathrm{ml}$ of extraction buffer ( $25 \mathrm{mM}$ Na-acetate, $\mathrm{pH}$ 4.5 and $1 \mathrm{mM}$ phenyl methyl sulphonyl fluoride), vortexed and left for $2 \mathrm{~h}$ at $4^{\circ} \mathrm{C}$. The extract was centrifuged at $10.000 \mathrm{rpm}$ at $0^{\circ} \mathrm{C}$ for $15 \mathrm{~min}$. and the clear supernatant was used as the total protein extract. Characterization and molecular mass determination of proteins were carried out using one dimensional SDS-polyacrylamide gel electrophoresis as described by Laemmli (1970).

\section{Statistical analysis}

All results were expressed as mean \pm SD of three replicates. Analysis of variance (ANOVA), a test for significant differences between means at $P \leq 0.05$ and $P \leq 0.01$, was performed to compare the impact of different treatments on growth and performance of the tested plants.All statistical analyses were performed using SPSS 17.0 software.

\section{Results and Discussion}

Cyanobacteria organisms are famous of biofertilization ability and their valuable contribution in soil fertility and plant development. Analysis of the used cyanobacterium cells showed a considerable amounts of pigments especially chlorophylls and phycobiliproteins (Table 1). A worthy content of carbohydrates and plant growth hormones were also recorded which could influenced the vigor of the produced seedlings in terms of seed germination and seedling morphological criteria compared to the control. In this study, the increment in germination percentage resulting from different cyanobacteria treatments was insignificant for Hordeum seedlings while significant for Trigonella ones (Fig. 1). Using different priming techniques improved seedling vigor, growth and yield of tomato, cucumber, chili, cabbage and watermelon crops (Maiti \& Pramanik, 2013); although the cultivars showed variation in germination percentage in responses to different treatments.In this respect, different cyanobacterial isolates showed a significant increase in percentage of germination of maize plant (Mohan et al., 2015).

In contrast to the minor increase in germination 
TABLE 1. Growth parameters and biochemical composition of $A$. variabilis culture (mean $\pm \mathrm{SD}, \mathrm{n}=3)$. * $(\mu$ mole $\mathrm{C}_{2} \mathrm{H}_{4} / \mathrm{ml}$ culture/day).

\begin{tabular}{lccc}
\hline \multicolumn{1}{c}{ Parameter } & Content & Parameter & Content \\
\hline PH & $7.8 \pm 0.01$ & Chl a (mg/g dry wt.) & $9.1 \pm 0.43$ \\
OD $(750 \mathrm{~nm})$ & $1.029 \pm 0.06$ & Carotene (mg/g dry wt.) & $1.07 \pm 0.22$ \\
Dry weight (g/l) & $0.873 \pm 0.03$ & Allphycocyanin (mg/g dry wt.) & $47.55 \pm 0.12$ \\
Carbohydrates (mg/ml) & $0.431 \pm 0.03$ & Phycocyanin (mg/g dry wt.) & $21.42 \pm 0.23$ \\
Proteins (mg/ml) & $0.163 \pm 0.06$ & Phycoerythrin (mg/g dry wt.) & $6.99 \pm 0.32$ \\
Lipids (mg/ml) & $0.151 \pm 0.1$ & IAA ( $\mu$ g/g dry wt.) & $180.5 \pm 1.6$ \\
$\begin{array}{l}\text { Exopolysaccharides } \\
\text { (mg/g dry wt.) }\end{array}$ & 145.12 & Gibberellins ( $\mu \mathrm{g} / \mathrm{g}$ dry wt.) & $337.9 \pm 3.9$ \\
Nitrogen N (\% dry wt.) & 9.863 & Cytokinins ( $\mu \mathrm{g} / \mathrm{g}$ dry wt.) & $82.76 \pm 1.2$ \\
Phosphorus P (\% dry wt.) & 2.12 & Nitrogenase Activity* & $102.2 \pm 7.8$ \\
Potassium K (\% dry wt.) & 2.75 & & \\
\hline
\end{tabular}

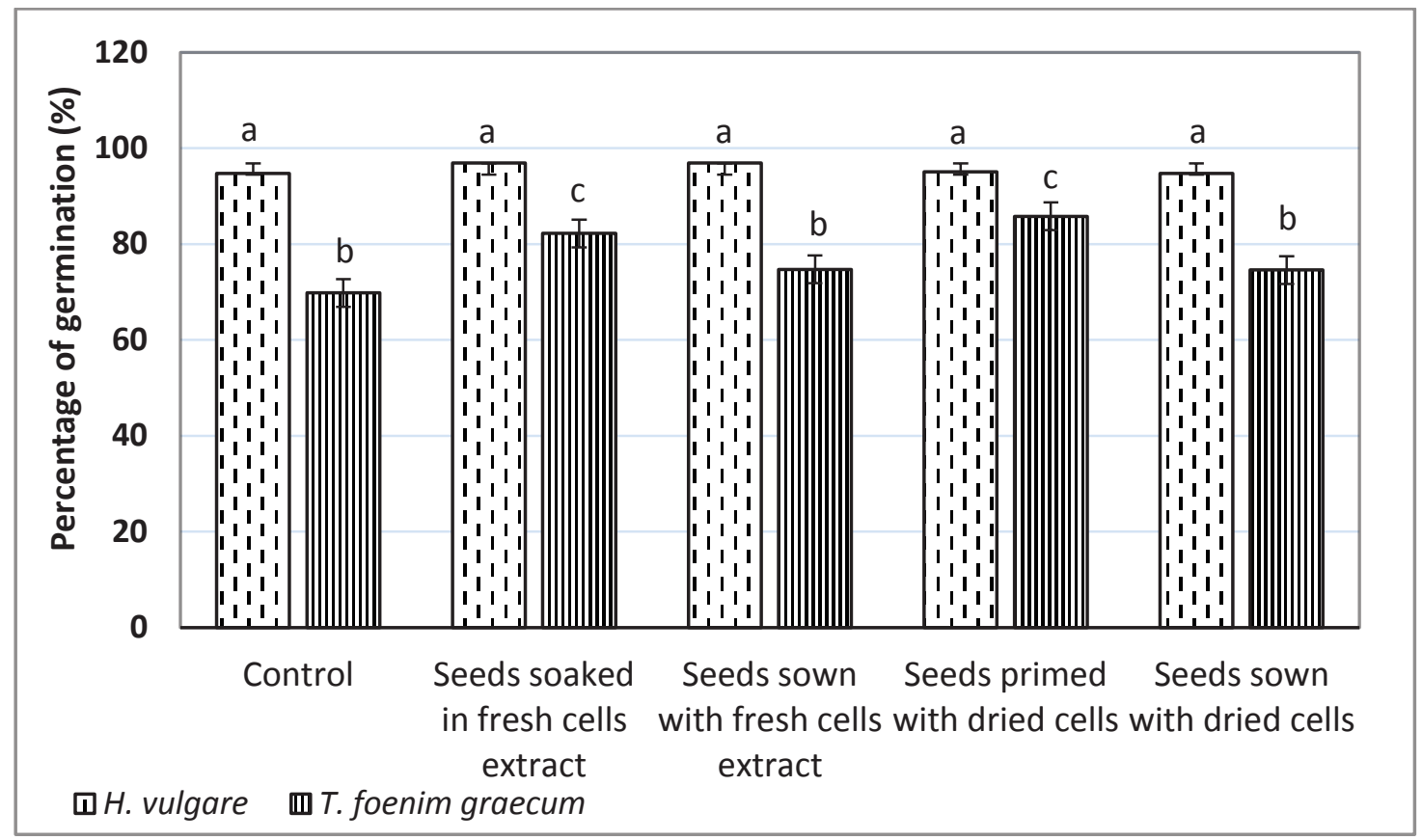

Fig. 1. Effect of $A$. variabilis on percentage of germination of 21 days old Hordeum vulgare and Trigonella foenumgraecum L. Similar superscript letters are not significant at 0.05 level of significance.

percentage, the growth and performance of Hordeum spand Trigonella sp. seedlings in terms of shoot length, shoot fresh and dry weight was highly significant enhanced, especially for barely seedlings, using different treatments of $A$. variabilis (Table 2).

Generally, the bio-priming treatment of seeds (seeds primed with dried cells) was superior in almost all the estimated morphological criteria followed by sowing seeds with dried cells. The promoting influence of cyanobacteria treatments affected seed quality causing an increase in shoots criteria in both studied plants. The bioactive substances such as auxins, gibberellins, cytokinins, proteins and lipids found in cyanobacteria cells were recorded to promote plant growth and development and increase the crop protection ability against soil harmful 
bacteria and fungi (Shariatmadari et al., 2013 and Gheda \& Ahmed, 2015). In addition, the presence of valuable carbohydrates, polysaccharides, $\mathrm{N}, \mathrm{P}$ and $\mathrm{K}$ in $A$. variabilis cells (Table 1 ) contributed

TABLE 2. Effect of A. variabilis on shoot growth parameters of 21 days old Hordeum vulgare and Trigonella foenum-graecum $\mathrm{L}$.

\begin{tabular}{|c|c|c|c|c|c|c|}
\hline \multirow{2}{*}{ Treatment } & \multicolumn{2}{|c|}{ Shoot length (cm) } & \multicolumn{2}{|c|}{ Shoot fresh weight (mg) } & \multicolumn{2}{|c|}{ Shoot dry weight (mg) } \\
\hline & Hordeum & Trigonella & Hordeum & Trigonella & Hordeum & Trigonella \\
\hline Control & $14.5 \pm 0.6$ & $9.9 \pm 0.9$ & $208 \pm 16.4$ & $196 \pm 11.4$ & $16 \pm 1.2$ & $11.2 \pm 1.1$ \\
\hline $\begin{array}{l}\text { Seeds soaked in } \\
\text { fresh cells extract }\end{array}$ & $26.2 \pm 0.5^{* *}$ & $10.9 \pm 0.8^{*}$ & $420 \pm 7.1 * *$ & $200 \pm 24.5$ & $20 \pm 1.6^{* *}$ & $12 \pm 1.2$ \\
\hline $\begin{array}{l}\text { Seeds sown with } \\
\text { fresh cells extract }\end{array}$ & $24.4 \pm 0.5^{* *}$ & $11.02 \pm 0.1^{*}$ & $340 \pm 14.1 * *$ & $248 \pm 35.6^{* *}$ & $20 \pm 1.6^{* *}$ & $12 \pm 0.7$ \\
\hline $\begin{array}{l}\text { Seeds primed with } \\
\text { dried cells }\end{array}$ & $31.1 \pm 1.1 * *$ & $\begin{array}{c}15.02 \pm \\
0.4^{* *}\end{array}$ & $396 \pm 21.9 * *$ & $380 \pm 20 * *$ & $28 \pm 2.2 * *$ & $20 \pm 1.6^{* *}$ \\
\hline $\begin{array}{l}\text { Seeds sown with } \\
\text { dried cells }\end{array}$ & $28.1 \pm 1.3^{* *}$ & $12.1 \pm 0.8^{* *}$ & $420 \pm 7.1 * *$ & $232 \pm 17.9^{*}$ & $28 \pm 1.6^{* *}$ & $16 \pm 0.7 * *$ \\
\hline
\end{tabular}

Mean $\pm \mathrm{SD}, \mathrm{n}=5$. $*$ Significant at 0.05 level and $* *$ Significant at 0.01 level of significance.

Results shown in Table 3 revealed fluctuated response of the photosynthetic pigments content between the two tested crop plants due to different cyanobacterial applications. A significant increase in $\mathrm{Chl} \mathrm{a}, \mathrm{Chl} \mathrm{b}$ and total pigments was recorded; being more pronounced with barley than fenugreek seedlings. However, the biopriming treatment with dried cells followed by sowing seeds with cyanobacteria dry cells proved to give higher pigment content over the other tested treatments and the untreated control. Oppositely, insignificant increase in carotenoids content was recorded with nearly all the examined treatments for both studied plants. The results are in agreement with those obtained by Hegazi et al. (2010) who proved that addition of cyanobacteria increased chlorophyll and carotenoid contents of bean plant. The promotive effect of the different cyanobacterial treatments may be due to high levels of GA3 in these treatments which can inhibit chlorophyllase activity (Haroun \& Hussein, 2003). In this concern, A. variabilis cells contained elevated levels of plant growth regulating hormones as IAA, gibberellins and cytokinins (Table 1) which may induce pigments biosynthesis and increase photosynthetic activities of the emerging seedlings. Shariatmadari et al. (2013) reported that cyanobacterial chemical composition (e.g. N, P\& K), nitrogenase enzyme activity and phytohormones stimulated rice plants growth. (Mazhar et al., 2013) suggested that wheat plants might release some signals leading to to their plant nutritive ability and soil fertility (Osman et al., 2005; El-Naggar et al., 2014 and Ismail \& El-Shenody, 2015). 
may change the mobilization of inorganic and organic nutrients from the storage cells to the emerging embryo and thus affecting plant growth and developments. The presented findings were also in conformity with Adam (1999), Shariatmadari et al. (2011) and Osman et al. (2016).

TABLE 3. Effect of $A$. variabilis on pigments content (mg/g fresh wt.) of 21 days old Hordeum vulgare and Trigonella foenum-graecum $\mathrm{L}$.

\begin{tabular}{|c|c|c|c|c|c|c|c|c|}
\hline \multirow{2}{*}{ Treatment } & \multicolumn{2}{|c|}{ Chlorophyll a } & \multicolumn{2}{|c|}{ Chlorophyll b } & \multicolumn{2}{|c|}{ Carotenes } & \multicolumn{2}{|c|}{ Total } \\
\hline & Hordeum & Trigonella & Hordeum & Trigonella & Hordeum & Trigonella & Hordeum & Trigonella \\
\hline Control & $\begin{array}{l}0.555 \\
\pm 0.06\end{array}$ & $\begin{array}{c}0.538 \\
\pm 0.005\end{array}$ & $\begin{array}{c}0.237 \\
\pm 02\end{array}$ & $\begin{array}{c}0.272 \\
\pm 0.003\end{array}$ & $\begin{array}{l}0.152 \\
\pm 0.03\end{array}$ & $\begin{array}{l}0.138 \\
\pm 0.03\end{array}$ & $\begin{array}{l}0.944 \\
\pm 0.06\end{array}$ & $\begin{array}{l}0.948 \\
\pm 0.02\end{array}$ \\
\hline $\begin{array}{l}\text { Seeds soaked } \\
\text { in fresh cells } \\
\text { extract }\end{array}$ & $\begin{array}{l}0.626 \\
\pm 0.04\end{array}$ & $\begin{array}{c}\mathbf{0 . 4 2 6} \\
\pm 0.03^{*}\end{array}$ & $\begin{array}{l}0.281 \\
\pm 0.05\end{array}$ & $\begin{array}{c}\mathbf{0 . 1 9 2} \\
\pm 0.04^{*}\end{array}$ & $\begin{array}{l}0.175 \\
\pm 0.02\end{array}$ & $\begin{array}{l}\mathbf{0 . 1 1 2} \\
\pm 0.01\end{array}$ & $\begin{array}{l}1.082 \\
\pm 0.1\end{array}$ & $\begin{array}{l}\mathbf{0 . 7 3 0} \\
\pm 0.05\end{array}$ \\
\hline $\begin{array}{l}\text { Seeds sown } \\
\text { with fresh } \\
\text { cells extract }\end{array}$ & $\begin{array}{c}0.740 \\
\pm 0.04 * *\end{array}$ & $\begin{array}{c}0.548 \\
\pm 0.003\end{array}$ & $\begin{array}{c}0.349 \\
\pm 0.05^{* *}\end{array}$ & $\begin{array}{l}\mathbf{0 . 2 5 2} \\
\pm 0.03\end{array}$ & $\begin{array}{c}0.217 \\
\pm 0.003 * *\end{array}$ & $\begin{array}{l}0.147 \\
\pm 0.02\end{array}$ & $\begin{array}{c}1.304 \\
\pm 0.04 * *\end{array}$ & $\begin{array}{l}0.948 \\
\pm 0.01\end{array}$ \\
\hline $\begin{array}{l}\text { Seeds } \\
\text { primed with } \\
\text { dried cells }\end{array}$ & $\begin{array}{c}0.788 \\
\pm 0.02 * *\end{array}$ & $\begin{array}{c}0.741 \\
\pm 0.01 * *\end{array}$ & $\begin{array}{c}0.434 \\
\pm 0.06^{* *}\end{array}$ & $\begin{array}{c}0.421 \\
\pm 0.02 * *\end{array}$ & $\begin{array}{c}0.164 \\
\pm 0.005\end{array}$ & $\begin{array}{c}0.150 \\
\pm 0.005\end{array}$ & $\begin{array}{c}1.387 \\
\pm 0.07 * *\end{array}$ & $\begin{array}{c}1.311 \\
\pm 0.006^{* *}\end{array}$ \\
\hline $\begin{array}{l}\text { Seeds sown } \\
\text { with dried } \\
\text { cells }\end{array}$ & $\begin{array}{c}0.694 \\
\pm 0.06 * *\end{array}$ & $\begin{array}{c}0.643 \\
\pm 0.12 *\end{array}$ & $\begin{array}{c}0.362 \\
\pm 0.04 *\end{array}$ & $\begin{array}{c}0.394 \\
\pm 0.07 * *\end{array}$ & $\begin{array}{l}0.161 \\
\pm 0.01\end{array}$ & $\begin{array}{l}0.142 \\
\pm 0.05\end{array}$ & $\begin{array}{c}1.217 \\
\pm 0.12 * *\end{array}$ & $\begin{array}{c}1.179 \\
\pm 0.24 *\end{array}$ \\
\hline
\end{tabular}

Mean \pm SD, $n=3$. *Significant at 0.05 level and **Significant at 0.01 level of significance. (In bold, -ve insignificant values).

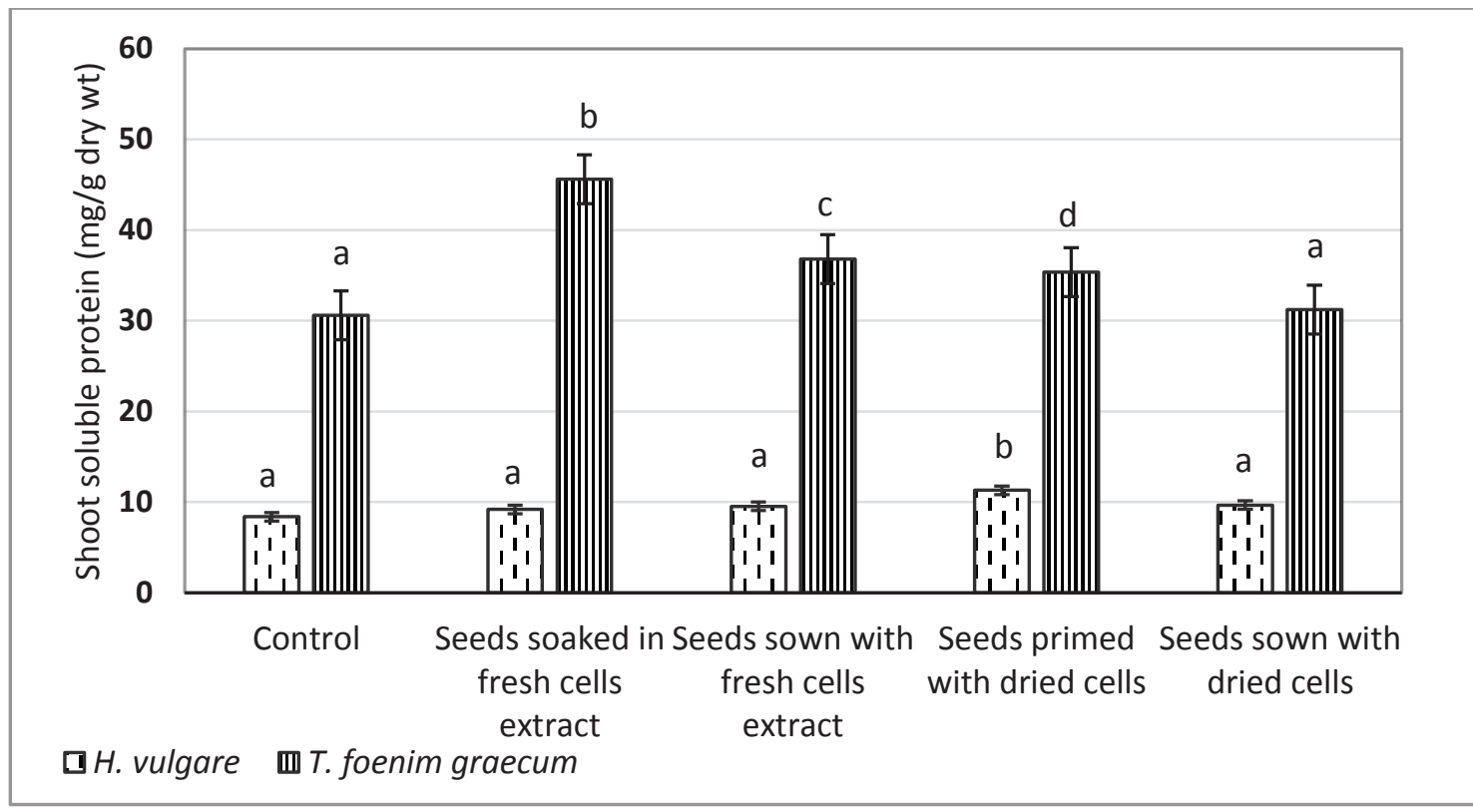

Fig. 2. Effect of $A$. variabilis on shoot soluble proteins (mg/g dry wt) of 21 days old Hordeum vulgare and Trigonella foenum-graecum $\mathrm{L}$. Different superscript letters are significant at 0.01 level of significance. 
The protein profile of Hordeum seedlings (Fig. 3) indicated the appearance of newly formed protein band with molecular weight of $220 \mathrm{KDa}$ in response to soaking the seeds in fresh cells extract compared with the control. It could be considered as treatment specific proteins (King, 1991) or revealed a changed pattern of gene expression after cyanobacteria treatments (Haroun \& Hussein, 2003). On the other hand, the protein profile of Trigonella (Fig. 3) shows the induction of low molecular weight protein bands ranging from 10-14 $\mathrm{KDa}$ with all treatments compared with the control. These low molecular weight proteins might represent phytohormones receptors (Davies, 1995). Moreover, such proteins may be used as an adaptive mechanism for application of a biofertilizers to give a maximum yield (Selvakumar et al., 2012). Depending on cluster analysis dendrogram, the protein patterns of Hordeum seedlings showed similarity above $(90 \%)$ under cyanobacterial treatments $2,3,4$ and 6 and above $(70 \%)$ under treatment 5 . On the other hand, different treatments affected the protein patterns in Trigonella seedlings more obviously with a homology percentage of only $(40 \%)$. However, cyanobacterial treatments 9,10 and 11 were closely similar (> 60\%). Generally, seeds primed with dried cells (treatments 5 and 10) revealed a pronounced effect on the protein profile of both studied plants (Fig. 3).
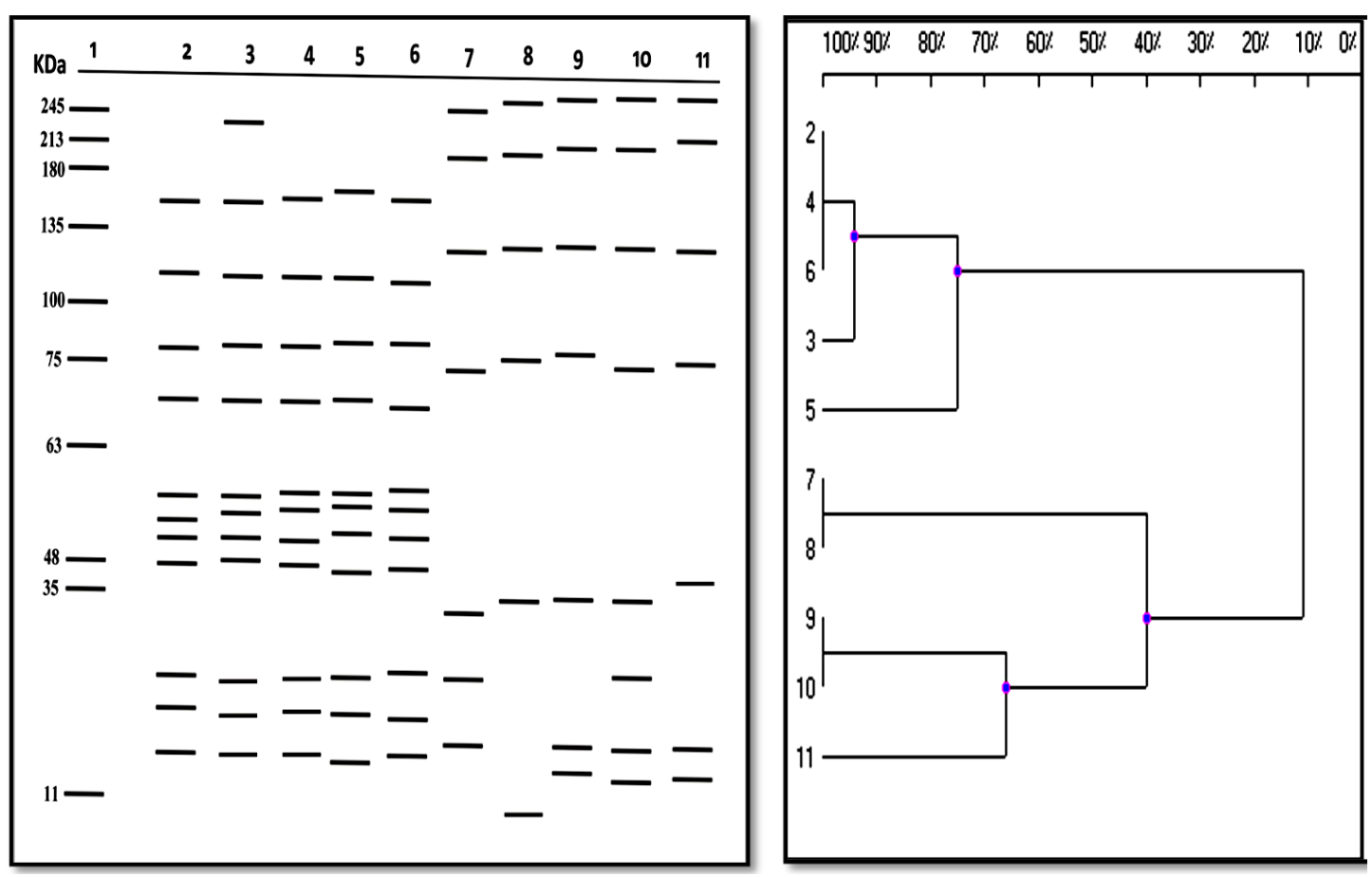

Fig. 3. Computer generated banding for SDS- PAGE protein patternof 21 days old Hordeum vulgare and Trigonella foenum-graecum L. seedlings under different $A$. variabilis treatments. Banding patterns were used to calculate a cluster analysis similarity dendrogram at $3.0 \%$ coefficient (UPGMA). (1= marker; 2\&7= Hordeum and Trigonella controls; $3 \& 8=$ seeds soaked in fresh cells extract; $4 \& 9=$ seeds sown with fresh cells; $5 \& 10=$ seeds primed with dried cells; $6 \& 11=$ seeds sown with dried cells.

The effect of $A$. variabilis on glutamateoxaloacetate transaminase (GOT) and glutamatepyruvate transaminase (GPT) activities of Hordeum and Trigonella leaves was shown in Fig. 4.The activity of GOT and GPT enzymes was significantly increased in most cyanobacterial treatments of the two tested plants. There was a pronounced increase in GOT activity in both Hordeum and Trigonella primed with dry alga compared with the control and the other treatments. In contrast, GPT activity was superior in Hordeum and Trigonella in which the seeds was sown with cyanobacteria cells extract (Fig. 4). GOT and GPT are among the key enzymes participating in nitrogen metabolism. The fluctuations in GOT and GPT activities reflect themselves on the biosynthesis of pyruvate, glutamate and oxaloacetate families of amino acids as well as the tricarboxylic acid cycle where pyruvic, oxaloacetic and $\alpha$-ketoglutaric acids are important for the cycle. 
Phytohormones present in A. variabilis (Table 1) may play an important role in enhancement of the biosynthesis of enzyme protein and / or enzyme activation. In this respect, Haroun \& Hussein (2003) found that the activities of protease and aminotransferase which are also important enzymes in nitrogen metabolism were increased in Lupinus termis plant as a result of seed priming in algal filtrates.Similar results were reported by Prasad et al. (2000) who noticed an increase in the enzyme activity (amylase, proteinase and starch phosphorylase) after presoaking of maize and cowpea plants seeds in a biofertilizer (whey) for $18 \mathrm{~h}$.

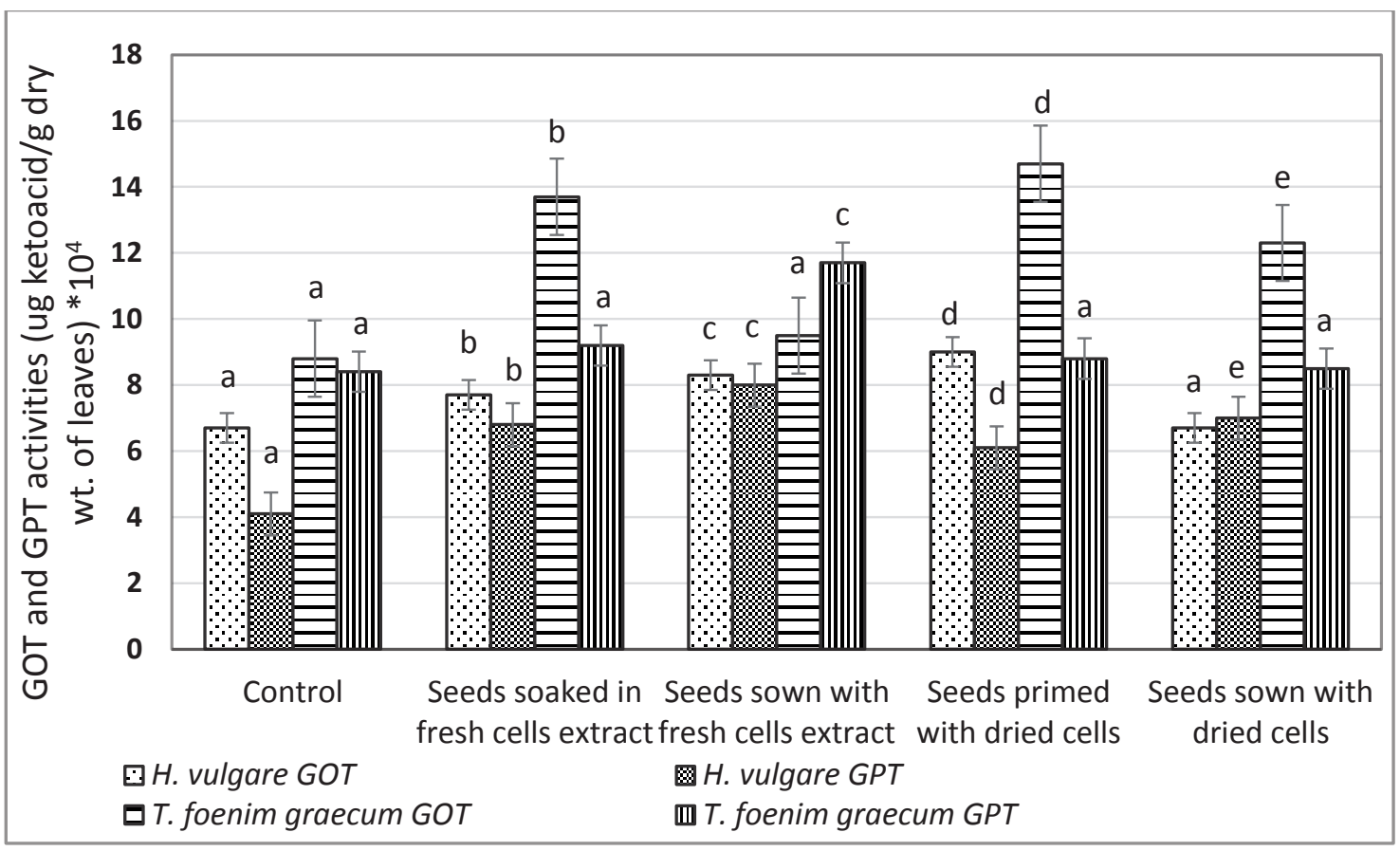

Fig.4. Effect of $A$. variabilis on glutamate-oxaloacetate transaminase (GOT) and glutamate-pyruvate transaminase (GPT) activities ( $\mu \mathrm{g}$ ketoacid/g dry wt. of leaves) of 21 days old Hordeum vulgare and Trigonella foenumgraecum L. Different superscript letters are significant at 0.01 level of significance.

\section{Conclusion}

It can be concluded that fresh or dry cyanobacteria as soil additives or as seed pretreatment improved plant nutrients which, in turn, enhances the biochemical routes that lead to a more rapid and proliferated plant growth. The bio-priming treatment of seeds with dried cyanobacterial cells was superior in almost all the estimated growth parameters and physiological processes of Hordeum and Trigonella studied plants. The results of the study recommended this technique as a promising tool for using cyanobacteria and algae as biofertilizers.

\section{References}

Adam, M.S. (1999) The promotive effect of the cyanobacterium Nostoc muscorum on the growth of some crop plants. Acta Microbiologica Polonica, 48(2), 163-171.

Allen, S.E., Grimshaw, H.M. et al. (1989) "Chemical
Analysis of Ecological Materials", $2^{\text {nd }}$ ed, Blackwell Scientific Publications, London. pp. 565.

Bergmeyer, H.U. (1974) "Methods of Enzymatic Analysis", Vol. II, Academic Press, London

Bradford, M.M. (1976) A rapid and sensitive method for the quantification of microgram quantities of protein utilizing the principle of protein dye binding. Analytical Biochemistry, 72, 248-254.

Chagnon, M., Kreutzweiser, D. et al. (2015) Risks of large-scale use of systemic insecticides to ecosystem functioning and services. Environmental Science Pollution Research International, 22(1), 119-134.

Davies, P. J. (1995) "Plant Hormones". Kluwar Academic Publishers, Dorrecht, The Netherlands. p.192.

Dubios, M., Gilles, K.A. et al. (1956) Colorimetric method for determination of sugars and related substances. Analytical Chemistry, 28(3), 350-356. 
El-Naggar, A.H., Osman, M.E.A. et al. (2014) Cyanobacteria mediated promotion of growth and some metabolic activities of barley seedlings. Egyptian Journal Experimental Biology (Bot.), 10(1), 63-73.

El-Nahas, A.I. and Abd El-Azeem, E.A. (1999) Anabaena variabilis as biocontrol agent for salt stressed vicia faba seedlings. Journal of Union Arab Biology, Cairo. Physiology of Algae,7(B), 169-178.

Gheda, S.F. and Ahmed, D.A.D.S. (2015) Improved soil characteristics and wheat germination as influenced by inoculation of Nostoc kihlmani and Anabaena cylindrica. Rendiconti Lincei, 26(2), 121-131.

Hardy, R.W.F., Burns, R.C. et al. (1973) Applications of the acetylene-ethylene assay for measurement of nitrogen fixation. Soil Biology and Biochemistry, 5, 47-48.

Haroun, S.A. and Hussein, M.H. (2003) The promotive effect of algal biofertilizers on growth, protein pattern and some metabolic activites of Lupinus termis plants grown in siliceous soil. Asian journal of Plant Science, 2(13), 944-951.

Hegazi, A.Z., Mostafa, S. S. M. et al. (2010) Influence of different cyanobacterial application methods on growth and seed production of common bean under various levels of mineral nitrogen fertilization. Nature and Science, 8(11), 183-194.

Ismail, G.A. and El-Shenody, R. (2015) Phycoremediation of sewage wastewaterA laboratory scale experiment study using microalgae. Egyptian Journal of Botany, (Special Issue for the $5^{\text {th }}$ International Conference of Botany and Microbiological Sciences, 15-16 April, 2015, pp. $155-172$.

Karthikeyan, N., Prasanna, R. et al. (2007) Evaluating the potential of plant growth promoting cyanobacteria as inoculants for wheat. European Journal of Soil Biology, 43, 23-30.

Kawalekar, S.J. (2013) Role or biofertilizers and biopesticides for sustainable agriculture. Journal of Bioinnovation, 2, 73-78

King, J. (1991) "The Genetic Basis of Plant Physiological Processes", Oxford Univ. Press, Oxford, New York, U.S.A, pp. 413.

Kirk, J. and Allen, R. (1965) Dependence of chloroplast pigment synthesis on protein synthesis: effect of actidione. Biochemical and Biophysical Research Communications, 21(6), 523-530.
Kursar, T.A., van der Meer, J. et al. (1983) Light harvesting system of red alga Gracilaria tikvahiae. I. biochemical analyses of pigment mutations. Plant Physiology, 73, 353-360.

Laemmli, U.K. (1970) Cleavage of structural proteins during the assembly of the head of bacteriophage T4. Nature, 227, 680 - 685 .

Lowry, O.H., Rosebrough, N.J. et al. (1951) Protein measurement with the Folin phenol reagent. Journal Biological Chemistry, 193, 265-275.

Maiti, R. and Pramanik, K. (2013) Vegetable seed priming: A low cost, simple and powerful techniques for farmers' livelihood. International Journal of Bio-resource and Stress Management, 4(4), 475-481.

Maqubela, M.P., Mnkeni, P.N.S. et al. (2008) Nostoc cyanobacterial inoculation in South African agricultural soils enhances soil structure, fertility and maize growth. Plant and Soil, 315, 79-92.

Mazhar, S., Cohen, J.D. et al. (2013) Auxin producing non-heterocystous cyanobacteria and their impact on the growth and endogenous auxin homeostasis of wheat. Journal of Basic Microbiology, 53, 996-1003.

Metzner, H., Rau, H. et al. (1965) Ultersuchungen Zur synchronisierbarkeit einzelner pigment mangel Mutanten von chlorella. Planta, 65, 186-194.

Mohan, A., Kumar, B. et al. (2015) Cyanobacterial consortium in the improvement of maize crop. International Journal of Current Microbiology and Applied Sciences, 4(3),264-274.

Osman, M.E.A., El-Naggar, A.H. et al. (2005) Effect of cyanobacterial biomass and exopolysaccharides inoculations on soil enzyme activities. El-Minia Science Bulletin, 16(1), 73-86.

Osman, M.E.H., Abo-Shady, A.M. et al. (2016) Cyanobacterial Arthrospira (Spirulina platensis) as safener against harmful effects of fusilade herbicide on faba bean plant. Rend. Fis. Acc. Lincei, 27(3), 455-462.

Prabhu, A. and Krishnamoorthy, M. (2010) on Ehrlich Ascites carcinoma in Mus musculus system.Journal of Pharmaceutical Research, 3, 1181-1183.

Prasad, B.K. and Kumar, M. et al. (2000) Effect of domestic wastes on the germination of maize and cowpea seeds. Journal of Phytological Research, 13, 191-194.

Reddy, P.P. (2013) "Bio-priming of Seeds. Recent Advances in Crop Protection", Springer India 2013, pp. 83-90. 
Rippka, R. Deruelles, J. et al. (1979) Generic assignments, strain histories and properties of pure cultures of cyanobacteira. Journal of General Microbiology, 111, 1-16.

Scott, J. M. (1998) Delivering fertilizers through seed coatings. Journal of Crop Production, 1,197-220.

Selvakumar, G., Reetha, S. et al. (2012) Responce of biofertilizers on growth, yield attributes and associated protein profiling changes of blackgram (Vigna mungo L. Hepper). World Applied Sciences Journal, 16(10), 1368-1374.

Shariatmadari, Z. and Riahi, H. et al. (2013) Plant growth promoting cyanobacteria and their distribution in terrestrial habitats of Iran. Soil Science and Plant Nutrition, 59(4), 535-547.

Shariatmadari, Z., Riahi, H. et al. (2011) Study of soil blue-green algae and their effect on seed germination and plant growth of vegetable crops. Rostaniha, 12(2), 101-110.

Sudo, H., Burgess, J. G. et al. (1995) Sulfated exopolysaccharide production by the halophilic cyanobacterium Aphanocapsa halophytica. Current Microbiology, 30, 219-222.

Taylor, A.G. and Allen, P.S. et al. (1998) Seed enhancements. Seed Science Research, 8, 245-256.

Ünyayar, S., Topcuoglu, S.F. et al. (1996) A modified method for extraction and identification of indole-3acetic acid (IAA), gibberellic acid (GA3), abscisic acid (ABA) and zeatin produced by Phanerochate chrysosporium ME 446. Bulgarian Journal of Plant Physiology, 22(3- 4), 105-110.

Vonshak, A. (1986) "Laboratory Techniques for the Cultivation of Microalgae". A. Richmond ed, Boca Raton:CRC Press.

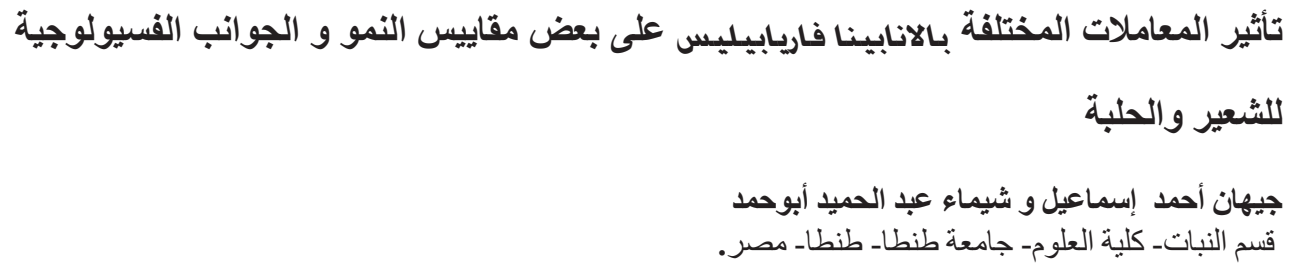

تعتبر السيانوبكتريا مجمو عه من بدائيات النواة التي تعيش في بيئات متنو عة. تستطيع هذه البكتريا أن تضيف

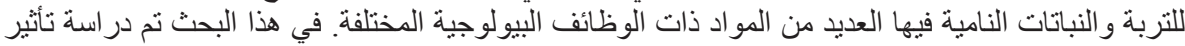

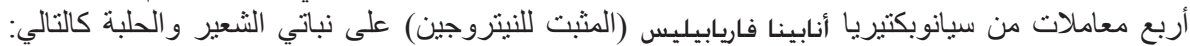

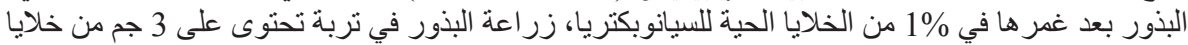

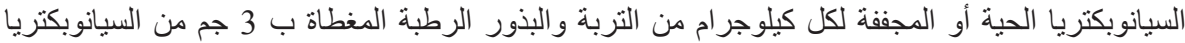

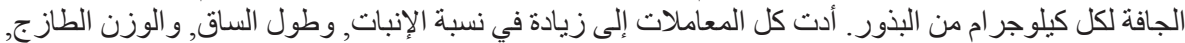

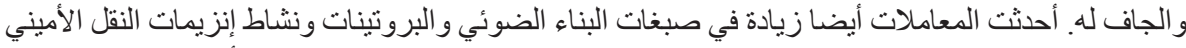

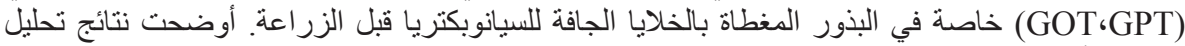

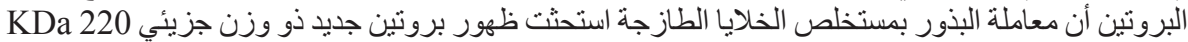

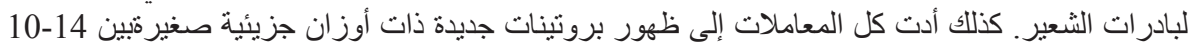
KDa

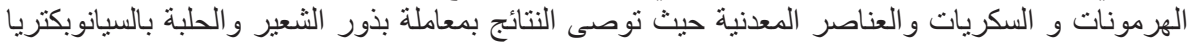

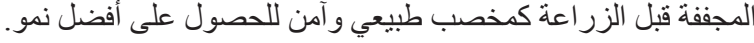

